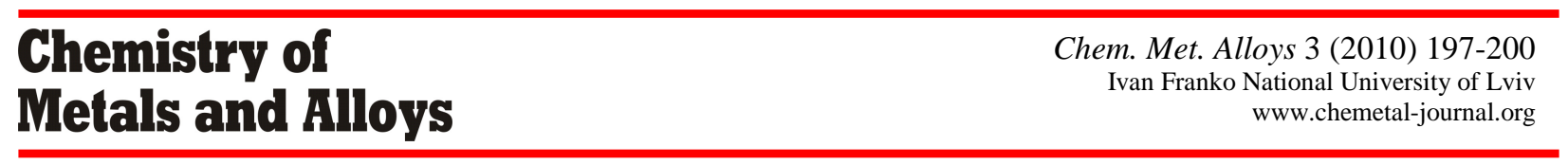

\title{
Parameters of the dendritic structure of copper alloys
}

\author{
Nikita MARTYUSHEV ${ }^{1 *}$ \\ ${ }^{1}$ National Research Tomsk Polytechnic University, Lenin Ave 30, 634050 Tomsk, Russia \\ * Corresponding author. Tel.: +7-382-2-419559; fax: +7-382-2-419559; e-mail: martjushev@tpu.ru
}

Received June 29, 2010; accepted October 29, 2010; available on-line March 2, 2011

The influence of the conditions of crystallization on the microstructure of a binary leaded bronze was examined. The conditions of crystallization were modified by changing the cooling speed of the melt through preliminary heating of the casting moulds. Quantitative regularities of the influence of the cooling rate on parameters of the dendritic cells and the grain size are presented. Data on the formation of lead inclusions between the dendrites of the copper matrix are also reported. It is shown that cooling rates of the order $100-150^{\circ} \mathrm{C} / \mathrm{s}$ lead to the formation of dendritic structures containing only axes of the first and second order. A decrease of the cooling rate at the moment of crystallization to less than $15^{\circ} \mathrm{C} / \mathrm{s}$ leads to the appearance of axes of the third order in the dendrite matrix.

\section{Dendrites / Bronze / Crystallization / Copper}

\section{Introduction}

Copper alloys, among which the most common is bronze, are used in mechanical engineering for manufacturing products with high antifriction and antiscoring characteristics such as, for example, sliding bearings. However, details made of these materials relatively often fail, not due to deterioration, but because of destruction. In some respects the mechanical properties and the possible outage of the details will depend on parameters of the microstructure, such as the size of the matrix grains, parameters of the dendritic cells, etc. [1,2]. Quantitative laws describing the influence of microstructure parameters of antifriction bronzes on their mechanical properties have been defined [3-5]. At the same time, the influence of crystallization parameters on the microstructure has only been studied qualitatively and research works presenting quantitative data concerning parameters of the microstructures formed under various conditions of crystallization are missing.

The aim of the present work was to investigate the influence of crystallization parameters on the formation of dendritic structures in bronze. The most examined crystallization parameter was the cooling rate, as it is often changed in practice [6].

\section{Experimental}

The samples used for the investigation were prepared by pouring molten bronze into graphite casting moulds and inducing subsequent crystallization at various cooling rates. The cooling rates were changed by preliminary heating of the casting moulds to various temperatures $\left(T_{\text {mould }}=20^{\circ} \mathrm{C}, v_{\text {cool }}=158^{\circ} \mathrm{C} / \mathrm{s}\right.$; $T_{\text {mould }}=200^{\circ} \mathrm{C}, \quad v_{\text {cool }}=137^{\circ} \mathrm{C} / \mathrm{s} ; \quad T_{\text {mould }}=400^{\circ} \mathrm{C}$, $v_{\text {cool }}=43^{\circ} \mathrm{C} / \mathrm{s} ; \quad T_{\text {mould }}=600^{\circ} \mathrm{C}, \quad v_{\text {cool }}=25^{\circ} \mathrm{C} / \mathrm{s}$; $T_{\text {mould }}=800^{\circ} \mathrm{C}, \quad v_{\text {cool }}=10^{\circ} \mathrm{C} / \mathrm{s} ; \quad T_{\text {mould }}=1100^{\circ} \mathrm{C}$; $v_{\text {cool }}=0.15^{\circ} \mathrm{C} / \mathrm{s}$ ) [7]. The chemical composition of the investigated bronze is given in Table 1 . The material has a two-phase structure: a copper matrix and small inclusions of lead $[8,9]$. In such a bronze the growth of copper dendrites is not influenced by any other factors when the cooling rate is changed.

Bronzes of a more difficult structure suffer the influence of other features affecting the phase structure and the form of the generated matrix dendrites. The influence of these factors will depend on the cooling rate as well and this will not allow an unambiguous interpretation of the results. The choice of a bronze containing $10 \%$ of a fusible phase was also motivated by the similarity of this concentration to bronzes used in industry (C92900, C93700, C93800), and inclusion of lead considerably improves the machinability of the samples.

Table 1 Chemical composition of the investigated material.

\begin{tabular}{c|c|c|c|c|c|c|c|c}
\hline \multicolumn{7}{c}{ Chemical composition (mass\%) } \\
\hline $\mathrm{Cu}$ & $\mathrm{Pb}$ & $\mathrm{Mg}$ & $\mathrm{Al}$ & $\mathrm{Si}$ & $\mathrm{S}$ & $\mathrm{Ti}$ & $\mathrm{Fe}$ & $\mathrm{Sn}$ \\
\hline 91.14 & 8.52 & 0.01 & 0.01 & 0.04 & 0.01 & 0.02 & 0.05 & 0.02 \\
\hline
\end{tabular}




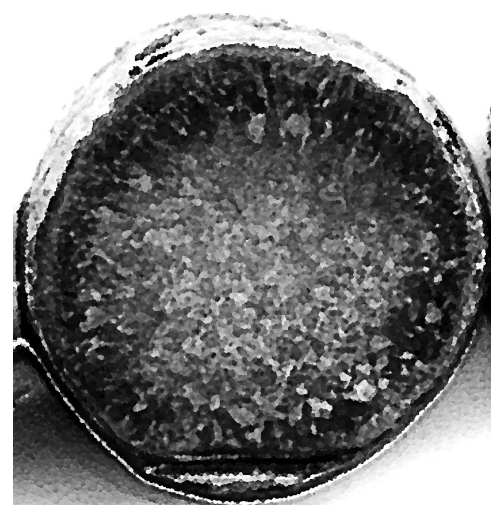

a

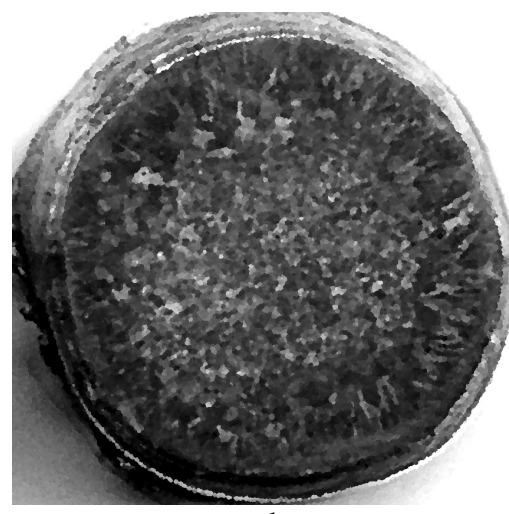

b

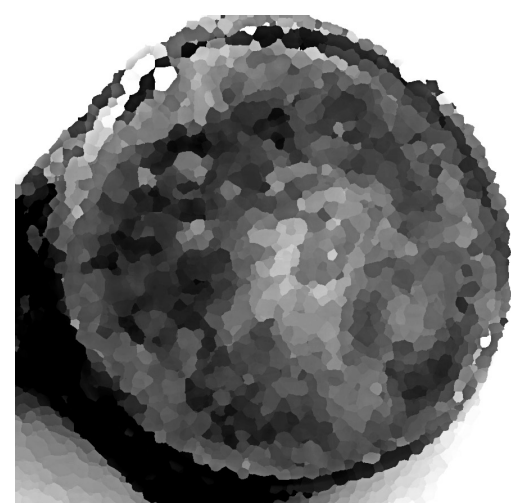

C

Fig. 1 Macrostructure of castings obtained at the cooling rates $158^{\circ} \mathrm{C} / \mathrm{s}(\mathrm{a}), 50^{\circ} \mathrm{C} / \mathrm{s}(\mathrm{b})$, and $10^{\circ} \mathrm{C} / \mathrm{s}(\mathrm{c})$.
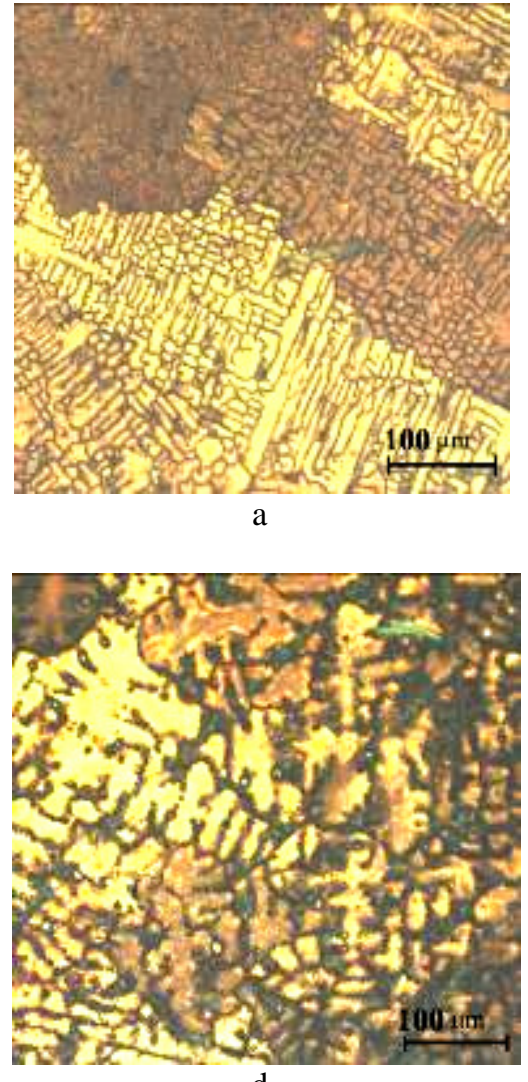

d

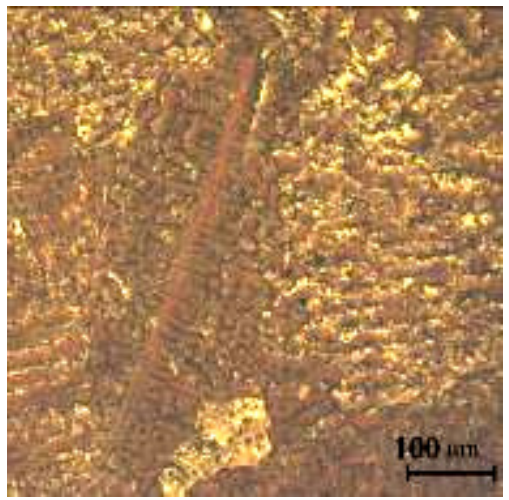

b

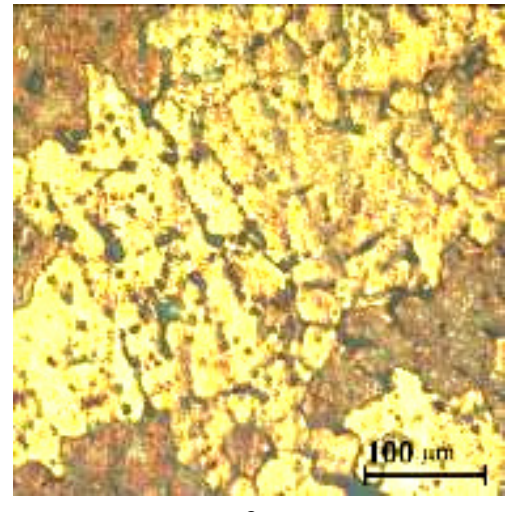

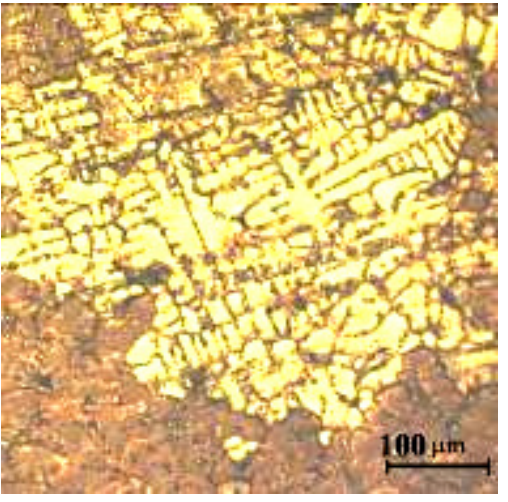

c

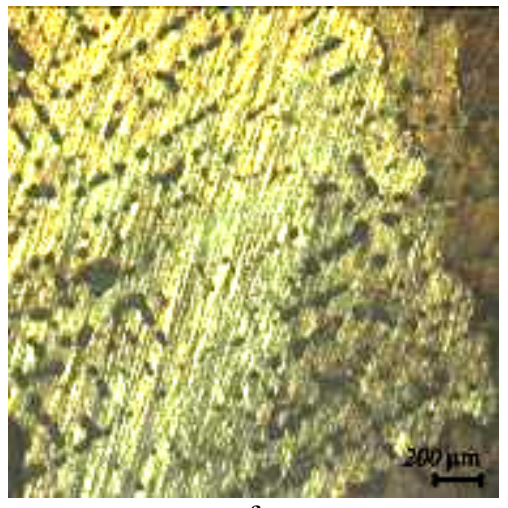

$\mathrm{f}$

Fig. 2 Microstructure of castings obtained at the cooling rates $158^{\circ} \mathrm{C} / \mathrm{s}(\mathrm{a}), 137^{\circ} \mathrm{C} / \mathrm{s}(\mathrm{b}), 78^{\circ} \mathrm{C} / \mathrm{s}(\mathrm{c}), 25^{\circ} \mathrm{C} / \mathrm{s}$ (d), $10^{\circ} \mathrm{C} / \mathrm{s}(\mathrm{e})$, and $0.15^{\circ} \mathrm{C} / \mathrm{s}(\mathrm{f})$.

The investigated bronzes were smelted in a high-frequency induction furnace from technically pure components in a silicicated graphite crucible. Deoxidation was made with phosphorous copper before adding lead into the liquid melt. The pouring temperature was $1080^{\circ} \mathrm{C}$ [10] and was controlled by a high-speed optical pyrometer TPT-90 with laser pointing. The casts represented cylinders with a diameter of $17 \mathrm{~mm}$ and a height of $70 \mathrm{~mm}$. The microstructure of the samples was studied on an optical microscope (Zeiss Axio Observer.A1m with a built-in in camera and Zeiss Axiovert 40 MAT); section etchings were not performed. The quantitative characteristics of the microstructure (percentage of the structural components and their average size) were determined by means of a local computer program [11], and with the help of the program complex delivered together with the abovementioned microscopes, by the techniques described in [12]. 


\section{Results and discussion}

The metallographic analysis revealed essential differences between the structures of mouldings cooled at different rates.

Fig. 1 shows the macrostructure of the moulding for different pouring temperatures. The typical view of the casting - the absence of contraction cavities near the free surface and the presence of a zone of columnar crystals (Fig. 1a) - proves directed cooling of the casting from an external surface, irrespective of the initial temperature of the mould. This occurs due to the small height and internal diameter of the casting. The visual analysis shows that at high cooling rates (Fig. 1a,b) the macrostructure of the casting presents the classical macrostructure of a stationary ingot and consists of three easily distinguishable zones: 1) zones of small crystals with $0.1-0.3 \mathrm{~mm}$ large crusts exclusively formed by homaxonic crystals no larger than $0.1 \mathrm{~mm}$; 2) zones of columnar crystals with a length of about $0.5-1.1 \mathrm{~mm}$, and 3) a central zone of $0.7-1 \mathrm{~mm}$ large homaxonic crystals. A reduction of the cooling rate (increase of the temperature of the casting mould) produces a decrease of the length and thickness of the columnar crystals, and at a cooling rate of $25^{\circ} \mathrm{C} / \mathrm{s}$ (Fig. 1c) this zone disappears completely. At the same time, grains grow in the central and peripheral zones of the casting so that on cooling below a speed of $1{ }^{\circ} \mathrm{C} / \mathrm{s}$ the size of the crystals at the casting centre reaches $1.5 \mathrm{~mm}$ or more. This indicates a more uniform cooling rate in the section of the casting during the whole period of crystallization.

On decreasing the cooling rate, a considerable amount of dendrites appears [13]. As shown in Table 2, a change of the cooling rate from $158^{\circ} \mathrm{C} / \mathrm{s}$ to 137 and $78^{\circ} \mathrm{C} / \mathrm{s}$ increases the distance between the axes of second-order dendrites by $17 \%$ and $33 \%$, respectively. A further decrease of the cooling rate leads to a more considerable growth of dendrites (Fig. 2f,g). At cooling rates lower than $25^{\circ} \mathrm{C} / \mathrm{s}$ the dendrites get axes of the third order.

The increase of the dendrites leads to grain growth. Dendrites of one color (or shading) in Fig. 2 form uniform grains. The dependence of the grain growth on the cooling rate is similar to the dependence of the distance between the axes of second-order dendrites on the cooling rate. At high cooling rates the grain size changes gradually, so that at a cooling rate of $158^{\circ} \mathrm{C} / \mathrm{s}$ the average diameter of the grains is about $200 \mu \mathrm{m}$, whereas at $137^{\circ} \mathrm{C} / \mathrm{s}$ it is $250-300 \mu \mathrm{m}$.

At lower cooling rates more active grain growth begins. A cooling rate of $25^{\circ} \mathrm{C} / \mathrm{s}$ gives an average diameter of the grains of about $600 \mu \mathrm{m}, 10^{\circ} \mathrm{C} / \mathrm{s}$ gives $\sim 1 \mathrm{~mm}$, and on cooling the casting in a mould preheated to $1100^{\circ} \mathrm{C}\left(v_{\mathrm{cool}}=0.15^{\circ} \mathrm{C} / \mathrm{s}\right)$, the size of the grains can reach several millimeters. The grain size is non-uniform throughout the casting section: on the surface the grains are smaller, and at the centre of the mould they are larger. For high cooling rates the
Table 2 Effect of the cooling rate on the distance between the axes of second-order dendrites in the investigated material.

\begin{tabular}{c|c}
\hline $\begin{array}{c}\text { Cooling rate, } \\
{ }^{\circ} \mathrm{C} / \mathrm{s}\end{array}$ & $\begin{array}{c}\text { Distance between the axes of } \\
\text { second-order dendrites, } \mu \mathrm{m}\end{array}$ \\
\hline 158 & 12 \\
137 & 14 \\
78 & 16 \\
25 & 25 \\
10 & 33 \\
0.15 & 120 \\
\hline
\end{tabular}

difference is a factor 2 or more; the ratio decreases with decreasing cooling rate and takes, for example, the value $1.3-1.5$ for $v_{\text {cool }}=10^{\circ} \mathrm{C} / \mathrm{s}$.

Fig. 2a,b shows that, for high cooling rates, lead in the form of very thin veins is distributed in interdendritic joints and on the borders of the grains. The shape of the inclusions is oblong and awkward. On reducing the cooling rate, rounded lead inclusions appear between the axes of second-order dendrites. Lead is practically not found between the dendrite joints of a grain, but settles mainly on the borders of the grains (Fig. 2e,f).

Increase of the cooling rate leads to a substantial increase of the quantity of matrix grains and reduces the time available for the process of separation of the liquid and the copper crystallites. The lead inclusions do not have enough time to coagulate. Besides, they appear surrounded by a crystallized matrix that impedes unification of particles of the low-melting phase. As a result the lead inclusions, crystallizing last, occupy free space. The form of their surface replicates the form of the surrounding copper dendrites. With decreasing cooling rate the quantity of matrix grains falls, their size increases, and the time available for the processes of stratification and crystallization increases. The lead inclusions now have the possibility to coagulate. The particles settle between the axes of second- and third-order dendrites.

\section{Conclusions}

A decrease of the cooling rate of the copper matrix of the investigated material naturally leads to the growth of dendrites and grains. At higher cooling rates, $120-160^{\circ} \mathrm{C} / \mathrm{s}$, the distances between the axes of second-order dendrites are in the range $10-15 \mu \mathrm{m}$. Consequently, the average diameter of a grain will be less than $200 \mu \mathrm{m}$. Axes of the third order will be absent in the matrix dendrites at such speeds. A decrease of the cooling rate of the mouldings during crystallization to $40-80^{\circ} \mathrm{C} / \mathrm{s}$ leads to the formation of undeveloped dendrite axes of the third order and to an increase of the grain size to $\sim 500 \mu \mathrm{m}$. Cooling at very slow rates (less than $1^{\circ} \mathrm{C} / \mathrm{s}$ ), as obtained by furnacecooling, produces considerable dendrite growth and a high average grain size. At such rates the distance 
between the axes of second-order dendrites reaches values of about $100 \mu \mathrm{m}$, and developed axes of third order appear. The diameter of some grains can reach several millimeters.

\section{References}

[1] M.A. Balter, A.P. Lubchenko, Fractography Means of Diagnostics of Destroyed Details, Mechanical Engineering, Moscow, 1987, 160 p. (in Russian).

[2] V.S. Zolotorevsky, Mechanical Properties of Metals: a Textbook for High-Schools, MISA, Moscow, 1998, 400 p. (in Russian).

[3] A.V. Kurdumov, M.V. Pikunov, V.M. Chursin, E.L. Bibikov, Casting of Non-Ferrous Metals, Metallurgia, Moscow, 1986, 416 p. (in Russian).

[4] A.V. Korchmit, Abstr. Diss. Cand. Techn. Sci., IMPA SB RAS, Tomsk, 2008, 28 p. (in Russian).

[5] U. Ozsarac, F. Findik, M. Durman, Mater. Des. 28 (2007) 345-350.
[6] A.A. Lebedev, L.I. Sokolskaya, Liteynoe Proizvodstvo (12) (1952) 15-18.

[7] N.V. Martyushev, I.V. Borisov, Yu.N. Petrenko, Proc. $15^{\text {th }}$ Int. Conf. Modern Techniques and Technologies, TPU, Tomsk, 2009, Vol. 2, p. 1920.

[8] D.I. Suchkov, Copper and Copper Alloys, Metallurgia, Moscow, 1967, 248 p. (in Russian).

[9] H.B. Cui, J.J. Guo, Y.Q. Su, H.S. Ding, S.P. Wu, W.S. Bi, D.M. Xu, H.Z. Fu, Trans. Nonferrous Met. Soc. China 16 (2006) 783-790.

[10] O. Teppo, J. Niemelä, P. Taskinen, Thermochim. Acta 185(1) (1991) 155-169.

[11] N.V. Martyushev, Yu.P. Egorov, O.M. Utiev, Proc. $8^{\text {th }}$ Int. Conf. Modern Techniques and Technologies, TPU, Tomsk, 2002, p. 159-161.

[12] L.V. Kostyleva, E.A. Santalova, V.A. Ilinskiy, Zavod. Lab., Diagn. Mater. (11) (2003) 32-35.

[13] N.M. Fetisov, N.A. Rumshin, V.M. Suponitskaya, V.I. Litovchenko, N.I. Repina, V.L. Rudnitskaya, V.F. Belozerov, Liteynoe Proizvodstvo (9) (1973) 26-27. 